水文 - 水資源学会誌

第 4 巻 3 号 (1991) $\quad$ PP. 3-14

\title{
都市の雨水水質管理の動向と課題
}

\section{和田 安彦*}

\section{I .はじめに}

都市の雨水は, 河川や下水道によってできるだけ 速やかに排除するという考えで管理されている。 し かし，近年，都市の過密化や郊外の都市化によって， 舗装・屋根などの不浸透域の増大, 下水道の整備に よる雨水流出の迅速化，田畑・森林等の緑地の減少 による保水・遊水機能の低下が進行している，その 結果, 都市域での雨水流出が早くなり, 降雨時に都 市河川水位が上昇し易くなって, 従来は浸水が生じ なかった降雨でも浸水が生じるようになっている。 さらに, 雨天時流出負荷の増加, 雨水の地下浸透量 の減少等から地下水位の低下や地下水を含めた水環 境の悪化が生じている。

このような情勢から都市では新しい考えに基づく 雨水の水量, 水質管理が必要となっている.ここで は，都市での雨水管理の現状と下水道の雨水管理に 果たしている役割を明らかにし，その上で，今後の 都市での雨水水質管理の課題を検討した。

\section{II. 都市の水と水㧓環}

1. 水の需要と再生利用
都市の水は都市を活かすもとであり，重要性が高 w.

わが国の淡水源賦存量は，豊水年度で 4,000 億 $\mathrm{m}^{3} /$ 年, 渴水年度で 3,000 億 $\mathrm{m}^{3}$ /年であり，これに対して 需要は農業用水 585 億 $\mathrm{m}^{3} /$ 年, 生活用水と工業用水が それぞれ 155 億 $\mathrm{m}^{3} /$ 年, 合計約 900 億 $\mathrm{m}^{3} /$ 年である. 需 要の地域的集中や季節変動, あるいは水を貯留する ことの困難性などから，淡水の利用率は限界に近い (平成元年度環境白書).

今後, 各用水共に需要の増大が予想されており, 水資源の不足への対応が重要な課題となっている. このため, 近年, 各種の廃水を再生利用して, この 問題に対処することが行われ，実施事例が年々増加 している．表一 1 に廃水を処理後雑用水として利用 している施設設置数の推移を示す.

廃水の再生利用の方法を大別すると,

(1)下水処理水の再利用

(2)ビル内排水のビル内での再生利用

(3)工場，事業所内での水の回収・循環使用

(4)工場, 事業所廃水の再生利用

以上の中で，工業用水での水の回収・循環使用は 全使用量75\%を占める程度にまで普及しているが,

表一 1 雑用水利用施設設置の推移2)

\begin{tabular}{|c|c|c|c|c|c|c|c|c|c|}
\hline 年 & $\sim 1965$ & $66 \sim 70$ & $71 \sim 75$ & $76 \sim 80$ & $81 \sim 85$ & 1986 & 1987 & 1988 & 1989 \\
\hline 件 & 10 & 27 & 70 & 167 & 389 & 66 & 63 & $(52)^{*}$ & - \\
\hline 累 & 10 & 37 & 107 & 274 & 663 & 729 & 792 & 844 & - \\
\hline $\begin{array}{l}\text { 罦計 内 訳 } \\
\text { ビルディング }\end{array}$ & & & 4 & 35 & 129 & 138 & 155 & 173 & 197 \\
\hline そ の 他 & & & 103 & 239 & 534 & 591 & 637 & 671 & - \\
\hline
\end{tabular}

（注）国土庁水資源部水資源政策課 $=$ 雑用水利用施設実態調查結果の概要（昭・63・8月）及び 工業新報社 $=\lceil$ 膜法中水道システ

* 年度不明分 
下水処理水の再利用は下水処理水量 $\left(80\right.$ 億 $\mathrm{m}^{3} /$ 年) の $0.7 \%$ (約 0.6 億 $\mathrm{m}^{3} /$ 年)（1987年度）と僅かである. 同様にビル内での水の再生利用実施率もまだ低い.

今後は, この分野での水の再生利用を積極的に推 進することが必要である.

\section{2. 水循環からみた都市化の间道}

水循環の観点からの都市化の問題には次のものが ある。

(1) 人口の高密度化による水需要の増大と, これ による水資源問題

（2）都市化地域からの水送污濁物質の増加と，こ れによる下水道等での負担増と水域水質污潭の 問題

(3) 市街地の拡大・高密度化に伴う不浸透域の拡 大と雨水排水系統の整備による雨水流出ピーク 流量の増大と雨水流出の集中化, 及びこれによ る都市型水害, 洪水の発生問題

(4) 不浸透域の拡大を原因とする地下浸透量の減 少による地下水位の低下や地下水を含めた環境 の水質悪化，都市内河川の基底流量の減少と流 量涸渴, 塩害等の問題の発生

\section{III. 下水道と都市の雨水管理}

\section{1. 都市の雨水管理}

都市の雨水管理は, 下水道と河川を中心に行われ ている. 下水道事業は当初, 雨水を速やかに排除し, 浸水を防除することが 1 番の目的であったが, 昭和 40年代以降, 水質污濁防止, 水洗化に上る生活環境 の改善が中心課題となり, 雨水管理に果たす役割は やや後退した，その後，下水道の普及がようやく一 つの段階にまで達したこと，及び生活を中心とする 環境への市民の関心，要望の高まりと社会・経済活 動に占める都市の比重の増大から, 再び下水道によ る雨水管理が重要視されるようになった。特に過密 化した都市では，雨水管理の一端を担う河川の改修 による雨水管理能力の向上が困難なことから, 下水 道の雨水管理に果たす役割は益々重要となっている.

都市での雨水流出対策は緊急性をもち，都市での 河川, 下水道による総合的な雨水管理の実施が必要 になっている。

\section{2. 下水道の役割}

下水道の果たす役割は大変幅広いものである. 従 来は,(1)地域の生活環境の整備向上, (2)健康管理 に 重点が置かれていたが, さらに, (3)広域的な公共用 水域の水質保全, (4)水資源の循環利用や資源保護に
まで大きな役割を持つようになってきた ${ }^{3)}$. 主な役 割は次のものである.

a) 地域の生活環境の整備向上

(1) 下水道の整備により低湿地の排水が良好に なり，浸水防止が図られる。

(2) トイレの水洗化によって快適で衛生的な生 活がおくれる.

(3) 污水が速やかに排除できるため，蚊や八エ の発生がなくなり，地域環境が大幅に改善さ れる。

(4) 土地の有効利用ができ, 道路の整備も行え る.

b) 健康管理

(1) 伝染病の発生を防ぐ.

(2) 毎日, 自己の最新情報に基づく健康管理が できる.

c）広域的な公共用水域の水質保全

(1) 国民的資産である自然環境を守り，保全す る.

(2) 各種用水の水質を守る.

(3) 水産資源を保護する.

(4)レクリエーションの活動の場としての水辺 や水環境を保全する。

(5)美しい水環境により，都市に快適な環境を もたらす。

d）水資源の循環利用

(1) 限りある水資源を守り,さらに付加価值を 高める。

(2) 水の再利用など資源の有効利用を図る.

\section{3. 都市での雨水流出と雨水制御方策}

1）都市雨水対策の現状

現在, 下水道の雨水排除での整備目標は, 大半の 都市で 5 年に 1 度の降雨に対して漫水が生じないこ ととしている.しかし，下水道の面的整備が終了し た地域でもその後の都市化の進展等により集中豪雨 時などでは局所的に浸水が発生していることもあり, 今後さらに都市の浸水安全度を高めていく必要があ る.このため, 市街地全域にわたって整備目標を 10 年に 1 度の降雨,さらには 20 年, 40 年とレベルアッ プしていくことが重要となっている.

例之ば，大阪府の寝屋川流域 (流域面樌270ki²) で は寝屋川流域都市水防災総合計画が策定され, 現行 の河川計画 $\mathrm{Q}=1,650 \mathrm{~m}^{3} /$ 秒を $\mathrm{Q}=2,700 \mathrm{~m}^{3} /$ 秒（治水 施設対応 $750 \mathrm{~m}^{3} /$ 秒, 流域対応 $300 \mathrm{~m}^{3} /$ 秒) とする計画 となっている. 
下水道での雨水排除では, 管きょやポンプ場を整 備し, 雨水を速やかに河川や海へ排除するのが基本 である.このため, 都市化によって増大した雨水流 出量に対応するには放流先河川の流下能力を向上さ せることが必要になるが, 高密度に都市化した地区 では用地取得の困難性や生活環境の維持・向上の側 面から都市河川の拡幅や堤防のかさ上げは極めて困 難である.このため, 都市では不十分な河川の流下 能力に依存しない下水道の整備が必要になってきて いる.

さらに, 都市域で発生する浸水は局所的に特定の 地域で発生することから，その状況に応じた対策も 必要となっている。

2）都市域での総合的な治水対策と雨水流出抑制 施設

(1) 都市域ての総合的な治水対策

都市での雨水流出対策は河川や下水道単独での対 応では対処できないため, 都市域全体, 流域全体で の総合的な治水対策の実施が必要である.これは治 水施設の整備を促進するとともに, 流域開発による 洪水流出量を極力抑制し, 流域の持つ保水・遊水機 能を維持するものである.

都市域における総合的な治水対策には, 施設整備 が中心のハードな対策と流域保全, 管理や情報シス テムからなるソフトな対策がある（図一 1).

これら対策の中でも流域での貯留と浸透による雨

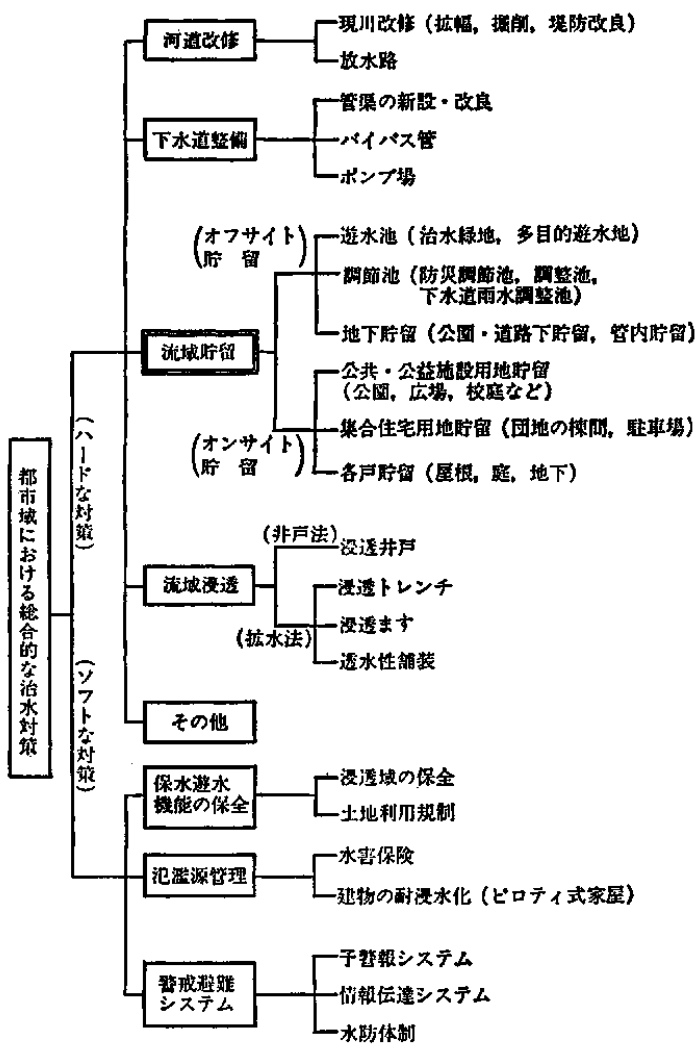

図一 1 都市域における総合的な治水対策

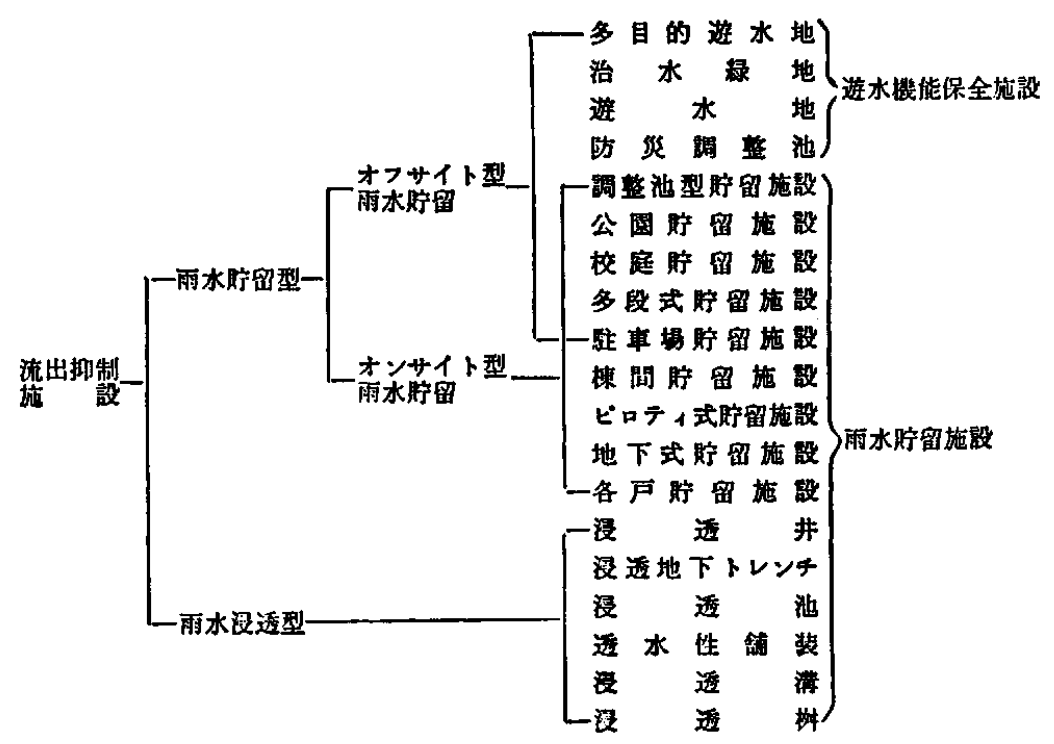

図一～流出抑制施設の分類 
水の流出抑制は, 緊急性を持つ都市の雨水流出問題 にすぐに対応できる方策であり，水環境の保全にも 寄与できるため, 現在, その整備が大都市を中心に 進められている。

(2) 都市域での雨水流出抑制施設

雨水流出抑制は流出雨水を一時貯留する貯留施設 と降雨を地中に浸透させて流出量をカットする浸透 施設が中心である。これらを一覧にしたものが図 ー2である。

これら施設は従来の下水道が雨水をできるだけ早 く流出させることを主眼に整備されてきたのとは異 なり，雨水を徐々に流すことや雨水を地下へ浸透さ せて表面流出量を減少させることを目指したものて ある，さらに，合流式下水道での越流負荷量を減少 させることゃ，污濁された雨水の一時貯留，雨水の 地下浸透等により，雨天時污濁対策の一つともなる。

雨水流出抑制型下水道システムの概念を図一 3 に 示す. 雨水流出抑制型下水道では，宅地，道路等に 降った雨水が下水道本管に達するまでの経路に様久 な浸透型施設を設置して雨水を極力浸透させるよう になっている，浸透しなかった雨水は下水道本管に 流入するが，河川へ流入するまでの間に管きょの遠 まわりや管内貯留によってさらに流出を遅らせるよ うになっている。

\section{N．都市での雨水水質管理}

\section{1. 都市での雨水水萁管理の基本的考え方}

1) 都市の雨水水質管理

都市での雨水水質を決定するものは，合流式下水 道越流水を除くと総てノンポイント污染源負荷であ る。都市でのノンポイント污染源負荷は主に屋根, 道路や道路側溝，排水路や下水管きょ内に堆䖽した 污濁物質が雨水流出と共に下流水域へ流出すること により生じる，したがって，都市での雨水水質管理 を行うには，合流式下水道からの越流の抑制とノン ポイント污染源負荷の流出を制御することが必要で ある.

2）合流式下水道越流抑制

合流式下水道の越流水対策には，合流式下水道に 流入する下水量，または污濁物質量を減少させる路 面清掃，雨水の貯留，地下への浸透と，管路施設て の遮集管きょ容量の増大，管きょ清掃，雨水滞水池 やスワール分水槽の設置等, さらに，処理場に流入 した雨天時合流式下水の処理レベルの向上等の改善 策がある。

以上の改善策をまとめて図一 4 に示す.

これらの改善策のどれを採用し，総合的に組み合 わせて有効な越流水対策を実施するかは，越流水対 策を必要とする地域毎に，下水道整備の程度，越流 水による污濁負荷の公共用水域に及ぽ影響，各改

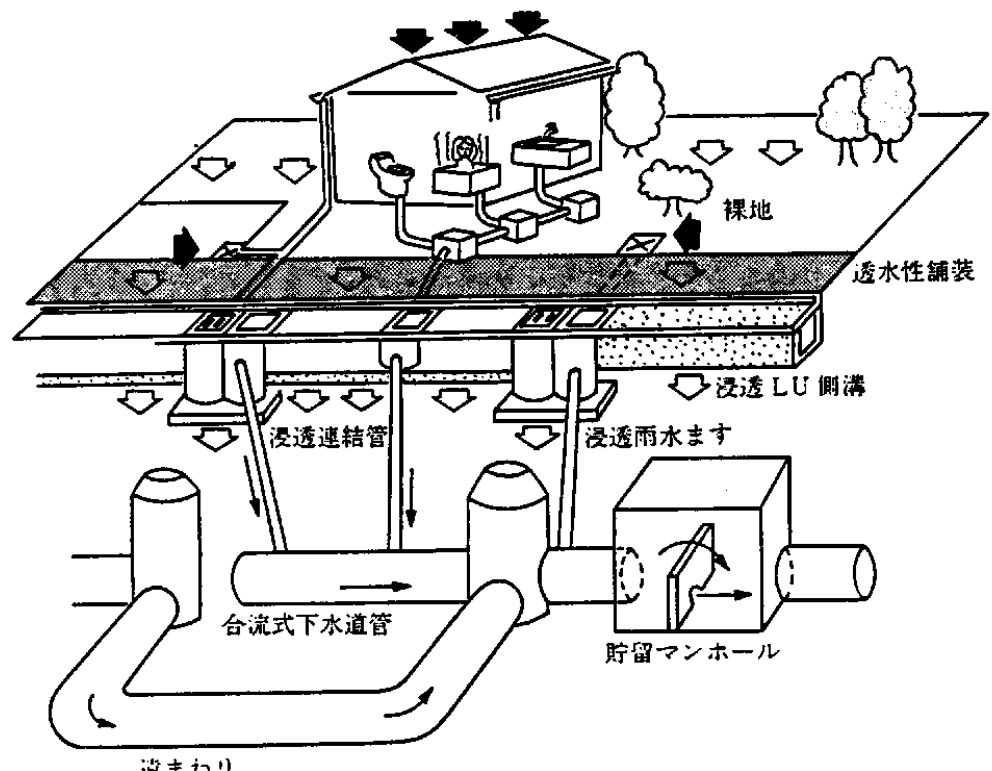

図一－雨水流出抑制型下水道システム 


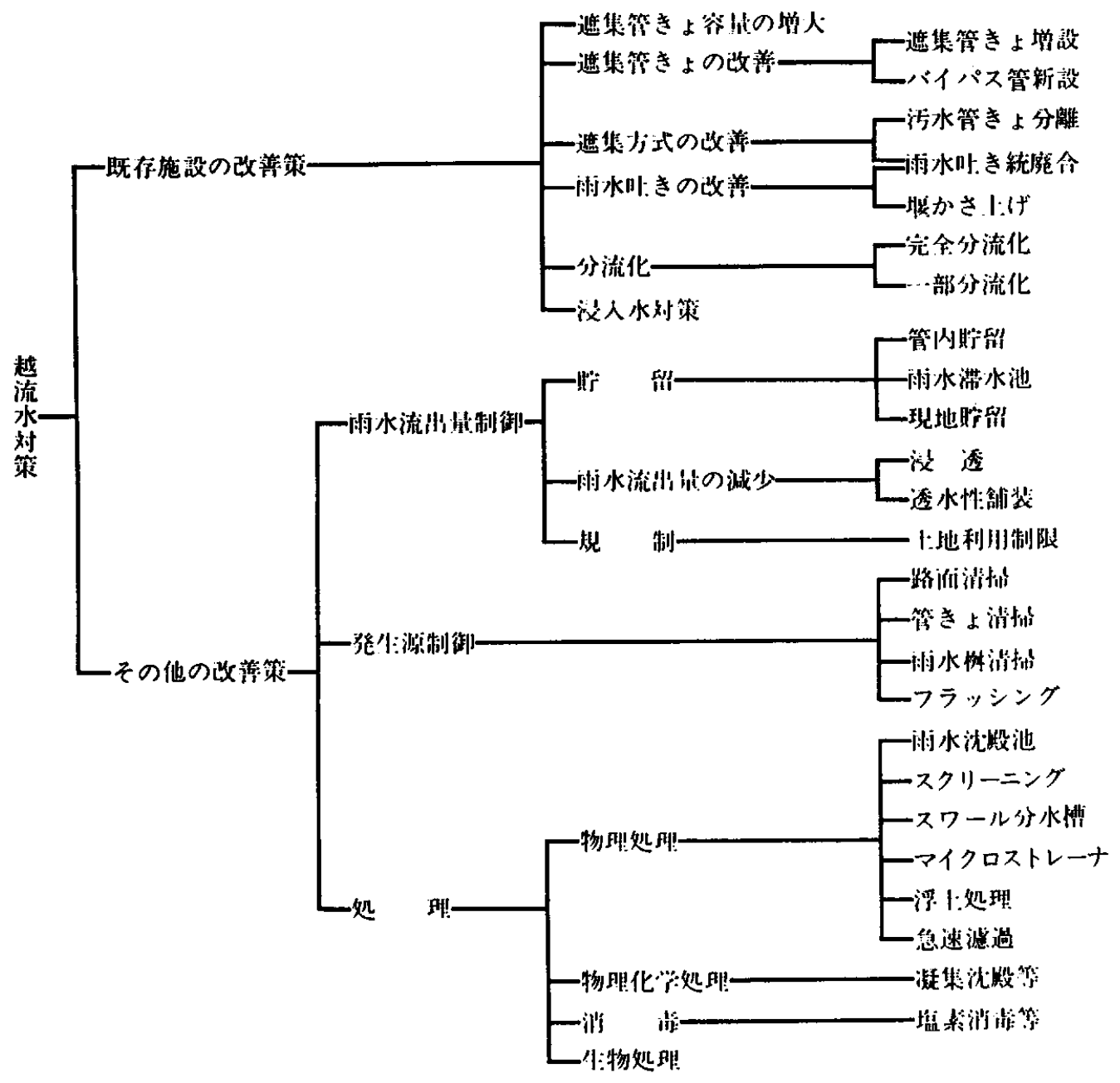

図一４越流水対策に扔ける改善策の分類

善策の地域における物理的及び費用的可能性等が地 域によって異なるので，地域毎の検討が必要である。

また, 雨水の貯留や地下浸透も併用した都市排水 管理を行う際には, 雨水滞水池を合流式下水道改善 策として設置するだけでなく, 浸水防除機能も併せ て行うように建設，管理するなど，合流式下水道の 越流水対策と他の施策とを組み合わせて, 総合的な 施策として実施することが有効である.

合流式下水道での雨水流出負荷を制御する方法と して, 以下のものがあげられる（合流式下水道越流 水対策と整定指針一1982年版一).

(1) 遮集管きょ容量の増大

越流水水質は, 一般に初期降雨時や小降雨時を除 けば都市雨水の水質と類似しているので，水質が悪
化している初期降雨時の下水をできるだけ遮集管 きょに送り, 水質的に都市雨水と類似した下水を越 流水として放流することが有効である。このため, 遮集管きょ容量を増大させれば, 越流水を減少でき, 処理場での雨天時合流式下水の処理量を増大させる ことになる.ここで，遮集管きょ容量は，晴天時污 水量に遮集雨水量を加えて定めるのが合理的である.

(2) 遮集方式の改善

図一 $5 \mathrm{a}$ に示すような遮集方式の場合, 遮集管きょ が合流幹線化して遮集下水を幾度も下流の雨水吐で 越流させてしまう。このため, 遮集方式を図一5b., $5 \mathrm{c}$.に示すように, 雨水吐きの統配合を含めた改善を 行引.

(3) 雨水吐きの改善 


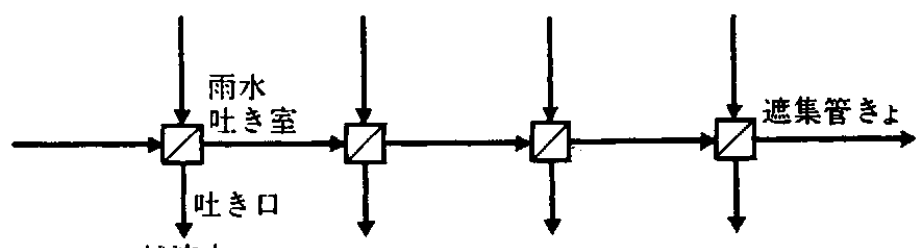

a. 改 善 前

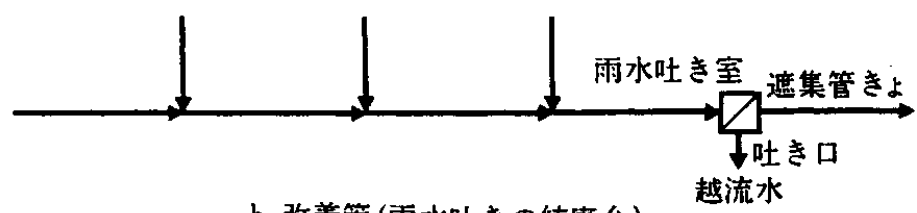

b. 改善策 (雨水吐きの統廃合)

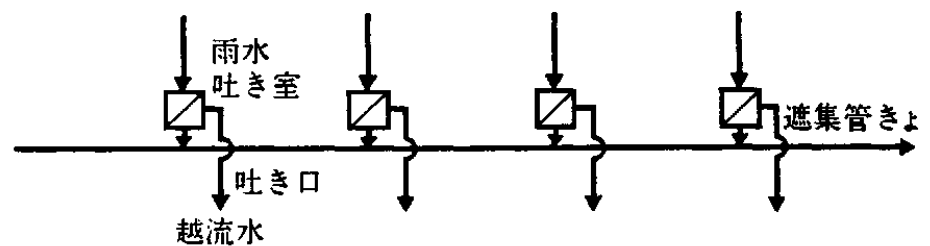

c. 改善策 (污水管きょの分離)

図一 5 遮集方式の改善(列4)

雨水吐きでの改善策としては, 雨水吐きの統廃合, 堰のかさ上げ，スワール分水槽等による雨水吐きの 改良, スクリーニング, 消毒等があるが, 雨水吐き の統廃合，娾のかさ上げなどが現実的である.

(4) 管内貯留

合流式下水道の場合は, 通常, 晴天時污水の流下 に要する管きょ断面の30～50倍の断面が雨水の流下 に必要な断面として設計されており, 計画規模以上 の降雨でないかぎりは，この管きょ断面のすべてが 満たされることはないため，この余裕分を利用する ものである.ただし，排水区域内の浸水防止のため には，管きょ内水位の低下が必要で, 何等かの制御 装置を用いて, 浸水の恐れがないように注意する必 要がある.

(5) 雨水滞水池

雨水滞水池は初期雨水及び雨水吐きやポンプ場か らの越流水を貯留し, 排水区域から放流される污濁 負荷量を減少させる施設であり, 雨水滞水池に貯留 した下水は降雨の終了後に処理場に送水して処理す るものである，処理レベルは放流先水域の環境基準 や水利用の状況等を勘案して決定する. 雨水滞水池 の事例を図一 6 に示す。

(6) 侵入水対策
施工後の管きょの不等沈下，老朽化等によって， 侵入水が計画値を上回る場合には, 雨水吐きからの 越流頻度の増加や, 処理場への流入下水量増加によ る処理施設の過負荷に起因する放流水質の悪化等の 問題が生じる.このため, 適切な維持管理を実施し て, 過剩な侵入水の有無を把挃し, 必要に応じて適 切な対策を高じる必要がある。

(7) 雨水沈㹂池

雨水沈澱池は沈瑖効果及び貯留効果を利用して, 雨天時合流式下水を処理する施設である. 雨水沈爿 池の事例を図一 7 に示す.

(8) スクリーニング

合流式下水道での雨天時の平均水質がBOD, COD では睛天時の平均水質を上回ることは少ないが, SS では雨天時には晴天時の約 2 倍程度にもなる。これ は雨天時には路面堆積物や管きょ内堆積污濁物質が 流出し, 雨天時合流式下水中に多量の粗大固形物や 浮遊物を含むためである.したがって，スクリーニ ングによってこれらを取り除くと，公共用水域への 浮遊性污濁物質の流出を抑制できる、スクリーニン グ設備にはマイクロストレーナ，ドラムスクリーン 等がある。

(9) その他 


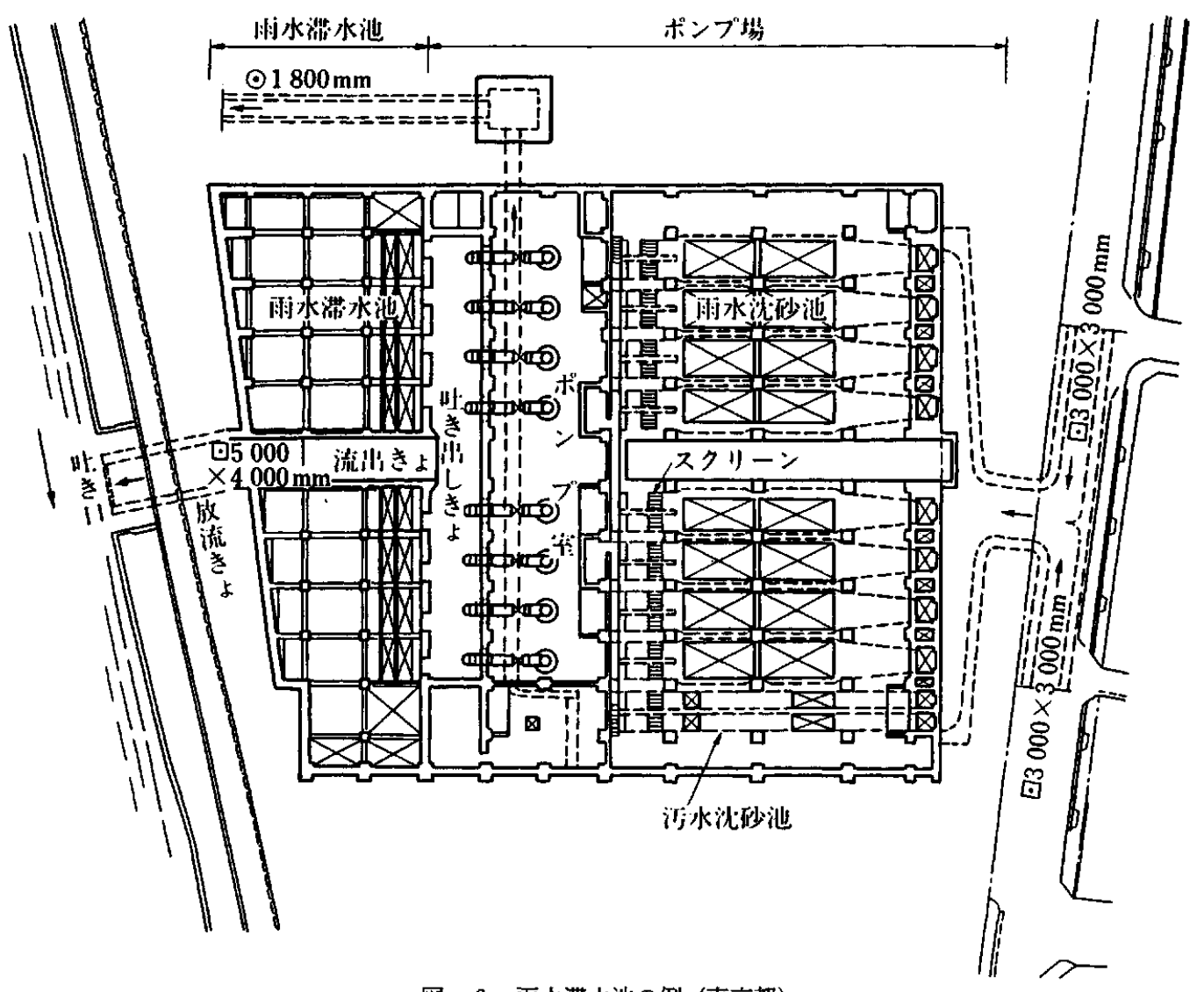

図一6 雨水滞水池の例（東京都）

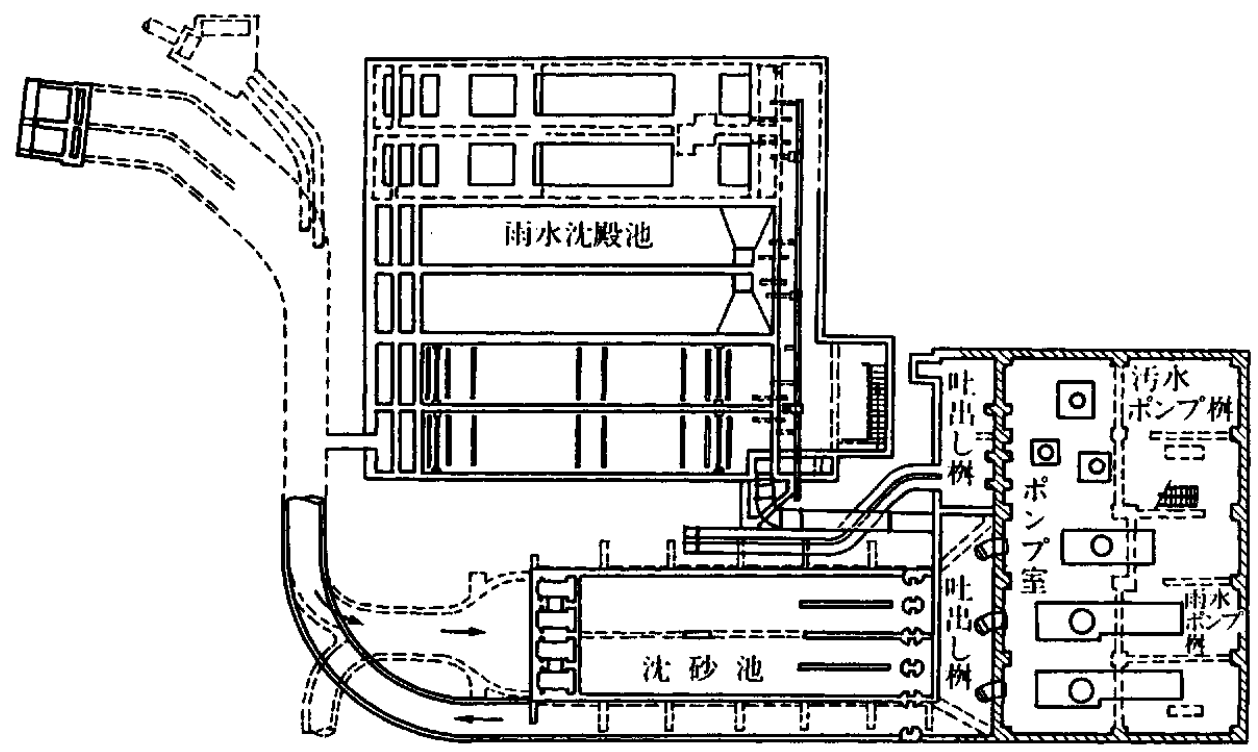

図一7 雨水沈殿池の例（大阪市） 
以上の方法の他に下水中の浮遊物を除去する浮上 処理，下水を不活性なろ材增をろ過させて下水中の 浮遊物を除去する急速ろ過等の雨天時合流式下水の 污潈負荷量を減少させる方法があるが，まだ技術開 発の段階である.

3) ノンポイント污染源負荷制御

都市部からのノンポイント污染源負荷を制御する には次の点が重要である.

(1) 個別対策の推進

都市部では雨水の流出抑制や道路, 側溝の清掃, , 合流式下水道の越流水の処理等, 種々のノンポイン 卜污染源負荷対策が実施されている.

したがって，都市部でのノンポイント污染源負荷 制御計画では，まず，これらの個別対策について継 続的なデータ収集を行い, 効果を評価して, 設置す ることが必要である。

また，下水道管きょや側溝，雨水桝の清掃実施な ぞ, 施設建設だけでなく, 雨水排除施設全体の維持 管理への取り組みのウエイトを高めていくことも必 要である。

(2) 住民による取り組みの推進

ノンポイトン污染源負荷はその性質上，面的な制 御が必要になる，面的な制御を実施する場合には， 行政による対策では限界があり, 住民の協力が不可 欠である。

具体的には, 住宅地周辺の道路や側溝, 雨水栘, 小水路等の清掃や適正なごみ処理, 庭や棟間, 駐車 場等を利用した雨水の一時貯留や浸透等がある.

このような住民による地域環境への取り組みを積 極化するには，広報活動による意識の高揚やマスコ ミを利用したキャンペーンの実施，各種問題の提示，
あるいは地域での勉強会の実施等, 様々な活動の実 施が必要である。

さらに，住民の地域環境に関する関心を高め，生 活と環境との関わりを認識させ,"自分達の環境は自 分達で守り，育てる”というような考えを持つよう にすることも大切である。

(3) 総合的な対策の実施とその評価

ノンポイント污染源負荷は様々な形態で発生し, 流出しているため，その対策も自ずと複雑になる. 実際, 直接的なノンポイント污染源負荷対策以外て も，治水対策，下水道整備事業や特定污染源対策も 間接的なノンポイント污染源負荷対策となる。した がって, 総合的にノンポイント污染源負荷対策を実 施するには，これらの諸対策を総合的に組合せ管理 して，効率的な運用を図り，より効果をあげれる様 に努めることが大切である。

この場合,これらの諸対策の効果を総合的に評価 できるシステムを確立しておくことが必要になる。 例えば，大規模雨水専用幹線や地下貯留池等のネッ トワーク化や雨水浸透型下水道の整備によるノンポ イント污染源負荷流出制御の効果をこれらの組合せ, 制御方式毎に検討，評価するシステムである.

これにより, 都市部での総合的なノンポイント污 染源負荷対策の実施が可能となる。

\section{2. 都市での雨水水管理の事例}

下水道による都市での雨水水質管理は，合流式下 水道越流水対策と分流式下水道雨水管からの流出対 策である，具体的には雨水滞水池や貯留管きょ等の 雨水販留施設が用いられている。近年,このような 施設の実施例は非常に多くなっているが，紙面上， その一例のみを示す。

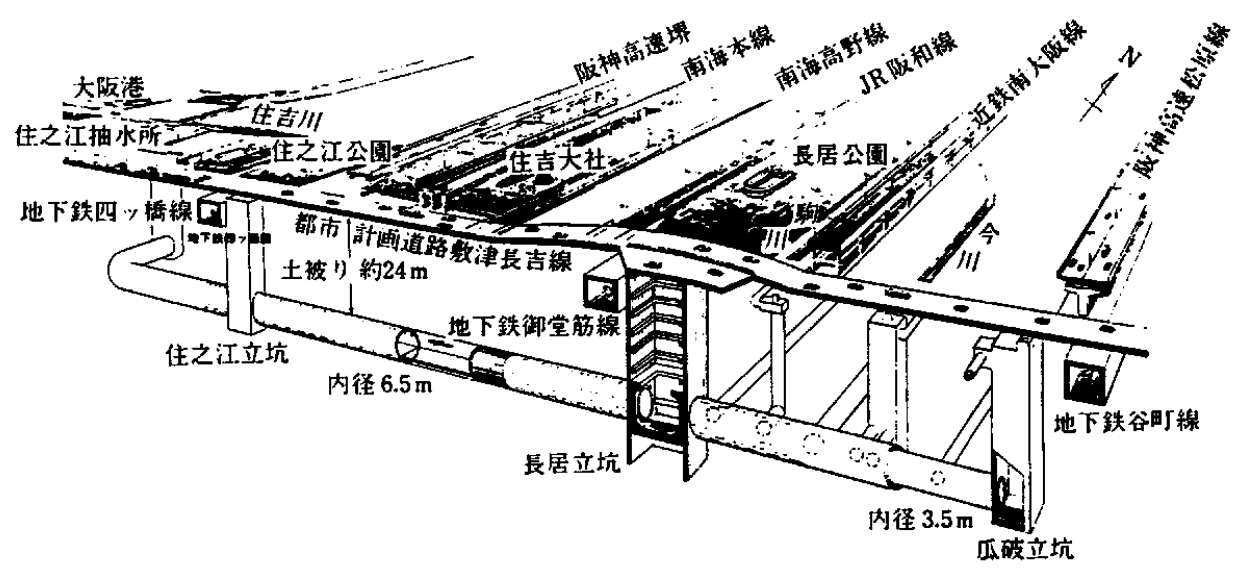

図一8 なにわ大放水路完成予想図 
1）なにわ大放水路

なにわ大放水路は大阪市東南部の下水道整備区域 内で集中豪雨時に発生している浸水の抜本的な対策 として建設されている雨水排除専用の大規模下水道 幹線である。

なにわ大放水路は，平野区から住之江抽水所に至 る幹線（延長 $8.5 \mathrm{~km}$, 内径 $6.5 \sim 3.5 \mathrm{~m}$, 最大土被り約
$29 \mathrm{~m}$ ) と, この幹線に接続する準幹線 ( 3 幹線, 延長 $3.7 \mathrm{~km}$, 内径 $5.0 \sim 1.65 \mathrm{~m}$ ), 及び住之江抽水所 (雨水 排水能力 $75 \mathrm{~m}^{3} /$ 秒) からなっている (図一 8 )。また, 事業年度は昭和 59 年度〜平成 7 年度の 12 年間であり, 事業費は960億円である。

なにわ大放水路では，浸水防止機能に支障を与え ない範囲で, 下水処理場で雨天時処理能力以上の合
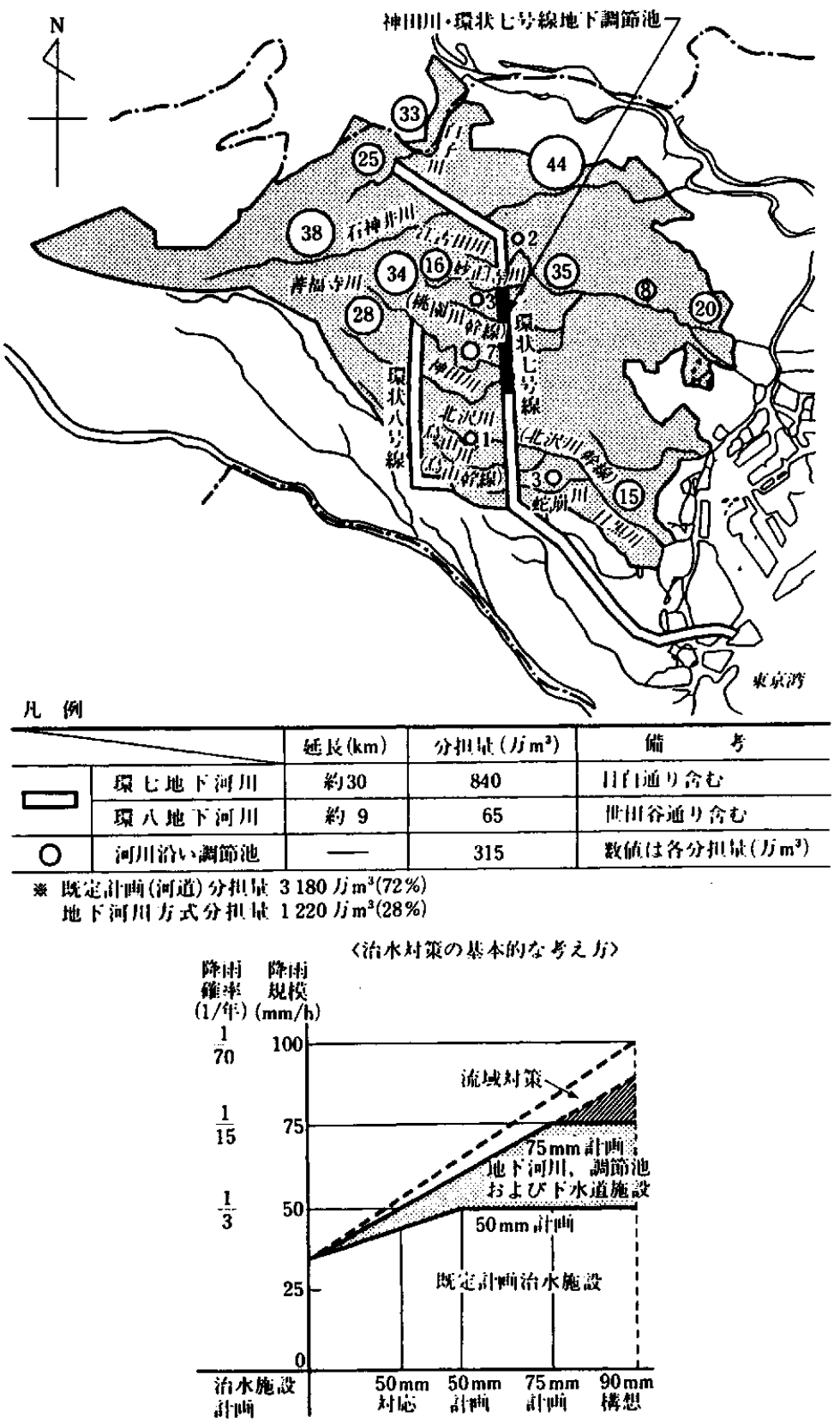

図一9＼cjkstart地下河川方式による75mm計画 
流式下水道雨天時下水を幹線内に貯留し, 雨天時未 処理放流污濁負荷量を減少する計画となっている。 また，貯留水の水質が基準値より高い場合には，貯 留水は処理場で処理をして放流される。

下水道幹線からなにわ大放水路へ流出下水を流入 させるために設置してある分水会所には，浸水対策 用の堰と合流式下水道改善対策用の堰がある.大阪 市での標準的な年間降雨デー夕を用いた対象地域で の雨水流出量, 流出污濁負荷量のシミュレーション

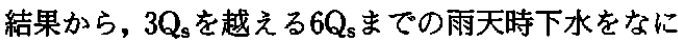
わ大放水路に貯留（最大貯留可能容量約 18.5 万 $\mathrm{m}^{3}$ ) することが最も効果的であることが明らかにされて いる.

昭和 60 年 3 月の着工以来精力的に建設が進められ ており, 平成 3 年には完成する幹線部分 $(6.7 \mathrm{~km})$ を 雨水の一時貯留池として供用を開始する計画となっ ている.

大阪市のような高密度な大都市では, 地上に雨水 対策用の下水道施設用地を確保することが難しいた め, 今後はこのような大深度地下空間を利用するこ とが重要になる。

2）環七地下河川（神田川・環状七号線地下調節 池)

東京都では, 現在, 治水施設の整備を $50 \mathrm{~mm} / \mathrm{hr}$ の降 雨（概ね 3 年に 1 回）を計画規模とする既定計画に 基づき進めている，しかし，治水安全度として十分 な規模ではないため，次の段階として過去に記録的 な豪雨と水害をもたらした狩野川台風クラスの75 $\mathrm{mm} / \mathrm{hr}$ の降雨 (概ね 15 年に 1 回) に対処していく計画 となっている。

山の手中小河川における $75 \mathrm{~mm} / \mathrm{hr}$ 規模を目指す新 たな治水対策としては，河川の再拡幅が用地確保の 面で極めて困難なことから，幹線街路の地下を利用 する地下河川を中心に，河川沿いに調節池を設置し て対処する「地下河川方式」が採用されている.

環七地下河川は，山の手中小河川の中流部を南北 に横断している都道環状七号線の地下に設置される ものである，上流端の白子川と石神井川，神田川， 目黒川の 4 水系10河川（下水道幹線含む）の洪水を 一時貯留しながら東京湾へポンプ排水する計画であ る. 総延長は約 $30 \mathrm{~km}$, 貯留量は 840 万 $\mathrm{m}^{3}$ でる(図 $-9)$.

現在は, 環七地下河川の一部, 水害が多発してい る神田川水系での神田川・環状七号線地下調節池(延 長 $4.5 \mathrm{~km}$, 内径 $12.5 \mathrm{~m}$, 貯留容量 54 万 $\mathrm{m}^{3}$, 地下約 $40 \mathrm{~m}$ )
の建設が進められている.

3 ) 今津貯留池

大阪市鶴見区南部の今津地区は寝屋川, JR片町 線, 平野川分水路に囲まれた面積約210haの区域で ある.この地区の下水は今津放出幹線によって城東 抽水所に集められ, 污水は放出下水処理場に送水さ れ, 雨水は平野川分水路に排水されている.

今津地区では近年の市街化の進展にともない, 雨 水流出量が増大し，地盤沈下ともあいまって，大雨 時には地区内の低地で浸水が発生している。この対 策として，今津地区では城東抽水所の増設が困難で あり，道路が狭く下水管増設の余裕がないため, 雨 水の一時貯留を行う雨水貯留池が地区のほほ中央に ある今津公園の地下に建設された。

貯留池の規模は東西 $136.3 \mathrm{~m}$, 南北 $43.4 \mathrm{~m}$, 深さ 14 . $4 \mathrm{~m}$ で, 貯留能力は $26,000 \mathrm{~m}^{3}$ でる。降雨時に下水幹 線の水位がある值にまで上昇すると, 雨水は堰を越 えて短時間に池内に流入するようになっている，貯 留池内は 4 つの池に分かれており, 降雨量に応じて 段階的に貯留量を増加させるようになっている．貯 留した雨水は降雨後に処理場へ送り, 処理後放流し ている.

\section{V. 今後の都市と雨水管理}

\section{21 世紀の都市の状況}

21世紀は都市化社会の時代といわれ，都市への人 口集中が極端に進むと考えられる，21世紀の都市の 状況として以下のものが予想される5).

(1) 21 世紀には 8〜9 割の人々が都市に居住する。

(2) 産業構造の転換, 経済社会の国際化, 技術革 新, 情報化が一層進展し, 都市の機能は高度化, 複雑化，複合化し，都市の果たす役割は現在以 上に重要になる。

(3) 地域の環境を保全・活用し，個性的でやすら ぎやうるおいのある都市環境づくりが行われる。

(4) 地下空間, 海洋空間の積極的な利用が図られ る.

このような21世紀における都市での雨水管理は， 各種行政機能，業務機能，情報等が高度に集積した 都市を浸水から防御するとともに，快適な都市環境 を創造するために，欠くことのできないものである。 このため, 都市の雨水管理は, 都市域全体での長期 にわたる実施計画にもとづいて確実に行われるべき 性格のものである。

具体的には河道改修, 下水道整備や流域での貯 
留・浸透等の施設的な対策と流域での保水遊水機能 の保全や警報システムの整備等の政策・情報管理で 対応していく．特に雨水の流出抑制は都市での水循 環の保全にも寄与できるもので, 今後一層重要にな るものと考えられる。

\section{21世紀の都市での雨水管理の方法}

21世紀の都市での雨水管理の方向としては, 現在 あるもの以外に, さらに高度化してゅくため, 次の ものが考えられる。

1) 大深度地下空間の利用

21世紀の都市では, 地上に下水道施設等の雨水管 理施設を建設することが，用地確保上困難であり， さらに都市での生活環境の質的向上を図るには質の 高いオープンスペースの確保が必要である。このた め, 大深度地下空間を高度に利用した大規模雨水幹 線の整備や貯留池・調整地の建設が今後の雨水管理 の主要な方策のひとつになると考えられる。

2）ネットワーク化

都市での浸水発生は局所的なため, ある排水区は 浸水していても隣接する排水区には余裕があって漫 水していないこともある。このため，各雨水管理施 設を排水区間，さらには都市間でネットワーク化し て, 都市圈全体での浸水防除の安全率を高めること が進められていくと推察できる。これにより雨水管 理システムの効率的運転管理が可能になり,さらに 施設の更新や地震等の災害時の施設の相互補完にも つながるため，雨水管理の信頼性を向上できる.

3）自動制御

コンピュータのハード技術とソフトな利用技術が 発達していくため, 将来の雨水管理施設の制御や ネットワーク化では, 各種の施設を個別に操作員が 制御するのではなく，コンピューターにより自動制 御し，遠隔操作することが主流になると考えられる．

この際, 熟練操作員に近い制御効果を示すことが できる制御システムが必要と考えられる。

\section{4 ) 空間利用}

雨水管理システムは数年, 数十年に 1 度の降雨に よる浸水に対処する施設であるため, 強雨時のみし か使われず，利用効率は他の都市施設に比較して低 い.このため，できるだけ多目的な利用を図り，付 加価值を高める必要がある. 多目的利用の方法とし ては, 貯留管内に処理場の相互連結管や污泥圧送管, あるいは処理場・ポンプ場等の遠隔制御用通信ヶー ブルを設置し，下水道施設のネットワーク化を図る ことがある6).
さらに, 滞水池, 貯水池やポンプ場の上部空間を 公園や防災広場，さらには他の都市施設や民間施設 との共同利用も多目的利用方法として考えられる。

5) 雨水管理のシステム化

降雨量, 雨水流出量の予測から管きょ内の水量, 水質の自動計測, さらには各種の雨水管理施設を最 適制御するために，雨水管理のシステム化が進むと 考えられる。

6）住民と密着した雨水管理

雨水の管理は住民の生活に非常に密着した事業で あるが，これまでの下水道事業等は地域全体の計画 的な視点からの事業推進が行われ，直接影響を受け る住民の意見を反映したものとは必ずしも言えな かった.

今後は, 雨水管理の実施が都市とその住民の環境 を向上させていくものであることを踏まえ，都市の 雨水管理を住民の立場から考えていくことが是非と も必要である。

7) 雨水水質対策

都市では様々な污濁物質が種々の活動と共に発生 し, 面的に広く堆積している。このような污濁物質 はノンポイント污染源負荷と呼ばれている。都市に おいては都市化の進行に伴いさらにノンポイント污 染源からの污罣負荷は増えているため, 都市の水域 を中心とする環境改善ではノンポイント污染源から の污濁物質を制御できる技術，システムの開発とそ の適用が必要となっている. 今後は, 都市㧍よびそ の周辺地域での水系を中心とする環境の保全・改善 には, ノンポイント污染源負荷の管理が不可欠な時 代になっていく．このため，特に污染の度合の高い， 降雨初期の流出成分（ファーストフラッシュ）を捕 捉し，污濁物質の除去を行うことが必要になる。

8）雨水等の水資源としての有効利用

都市での慢性的な水不足問題の解決と都市での消 費エネルギー量の抑制のために, 都市への降水を有 効利用することである。

一般に家庭で使う水の $30 \%$ 強は水洗便所洗浄水が 占めている。これに錰植えや街路樹等への散水, 洗 車等を加えると家庭で使う水の $1 / 3$ は飲料水として の水質を必要としないものである，節水型の都市を 目指すには，このようないわゆる雑用水に雨水を利 用することが必要になると考えられる。

各家庭で雨水を貯め, 水洗便所洗浄用水等の雑用 水に利用したり，地区で雨水をタンク等に貯め，防 火用水や災害時の飲料用水に用いることが考えられ 
る.

また，治水対策用の雨水貯留施設に貯留した雨水 を次のように有効利用する方法が考えられる。

(1) 小川やせせらき等の環境用水として利用し, 都市環境のレベルアップを図る。

(2) 蒮用水として利用する.

(3) 火災や地震時等の非常時に消防用水, 緊急用 水として利用する.

\section{引用文 献}

1) 平成元年度懪境白書, 㻴境庁.

2）金山彦喜, 山本和夫: 工場廃水の再生利用と膜
分離技術の応用, 工業用水，第384号，1990年 9 月.

3）土木教程選書衛生工学, 末石富太郎編, 住友 恒, 山田 淳, 和田安彦共著, 鹿島出版会, 1987 年 5 月.

4) 合流式下水道越流水対策と管定指針一 1982 年版 一, 建設省都市局下水道部監修, 日本下水道協 会.

5）和田安彦：都市雨水対策と水筫問題，新都市， 1989年.

6) 竹石和夫: 都市雨水対策と下水道, 新都市, 1989 年. 